\title{
Seismic Strengthening of Low Strength Concrete Columns using High Ductile Metal Strap Confinement: A Case Study of Kindergarten School in Northern Thailand ${ }^{\dagger}$
}

\author{
Thanongsak IMJAI ${ }^{1, *}$, Monthian SETKIT ${ }^{1}$, Reyes GARCIA ${ }^{2}$, \\ Piti SUKONTASUKKUL ${ }^{3}$ and Suchart LIMKATANYU ${ }^{4}$
}

${ }^{1}$ School of Engineering and Technology, and Center of Excellence in Sustainable Disaster Management, Walailak University, Nakhon Si Thammarat 80160, Thailand

${ }^{2}$ School of Engineering, The University of Warwick, Coventry, United Kingdom

${ }^{3}$ Department of Civil Engineering, King Mongkut University of Technology North Bangkok, Bangkok 10800, Thailand

${ }^{4}$ Department of Civil Engineering, Prince of Songkla University, Songkhla 90110, Thailand

\section{("Corresponding author's e-mail: thanongsak.im@wu.ac.th)}

Received: 20 June 2019, Revised: 26 January 2020, Accepted: 8 February 2020

\begin{abstract}
The 2014 Chaing Rai earthquake (Thailand) caused extensive damage in many reinforced concrete (RC) buildings built before the introduction of modern seismic design guidelines. Much of the damage on these buildings was attributed to the inadequate capacity and/or ductility of columns. As a result, suitable and cost-effective strengthening techniques for such substandard elements are necessary. This article presents a case study on the seismic strengthening of a one-story RC kindergarten school located in Ampor Pan, Chaing Rai province. The building was partially damaged during the afore-mentioned earthquake, which led to cracking in walls, columns, and beam-column joints. As part of the initial assessment, innovative repair solutions were sought to minimize construction time, labor, and material cost. Accordingly, an innovative strengthening technique that uses Post-tension Metal Strapping (PTMS) was proposed to strengthen the damaged RC elements. This article presents details of the structural assessment performed on the building, as well as details of the PTMS strengthening strategy, which was applied for the first time in a real full-scale structure. This article contributes towards the validation and application of the PTMS strengthening on real structures, which had not been possible until now.
\end{abstract}

Keywords: Post-tension metal strapping, PTMS, Structural engineering assessment, Seismic assessment, Strengthening

${ }^{\dagger}$ Presented at the $2^{\text {nd }}$ International Symposium on Construction Innovation Research \& PhD Symposium: July 18-19, 2019. 
http://wjst.wu.ac.th

\section{Introduction}

Much of the existing building stock in Thailand has been designed according to old standards and often suffers from poor quality materials and inadequate construction practices. As a result, these structures have deficient seismic load resistance and can collapse under extreme loads, as observed during the Mw 6.1 Mae Lao earthquake that struck northern Thailand in 2014. The Mae Lao earthquake is the largest earthquake recorded in Thailand and caused the largest amount of losses in modern Thai history (US\$ 300 million [1]). More than 15,000 buildings were damaged, including 20 that collapsed and over 400 that were severely damaged. The earthquake also caused liquefaction and lateral spreading ground failures as far as $30 \mathrm{~km}$ from the epicenter. The earthquake sequence disrupted the population of Chiang Rai province, resulting in 1 death and 107 injuries; in total, more than 50,000 people were affected by the earthquake. Many collapses in buildings were attributed to inadequate reinforcement detailing of beamcolumn joints and to the use of low strength concrete [2-5]. Figure 1-left shows a partial collapse of a building due to beam-column joint failure during the 2014 Mae Lao earthquake (Chiang Rai, Thailand), whereas Figure 1-right shows typical substandard detailing observed in such beam-column joints. Although an up-to-date seismic design code was enforced in Thailand in 2007, the code does not provide guidance on vulnerability assessment of existing deficient buildings. Moreover, it is necessary to find suitable strengthening solutions to reduce the vulnerability of these buildings.
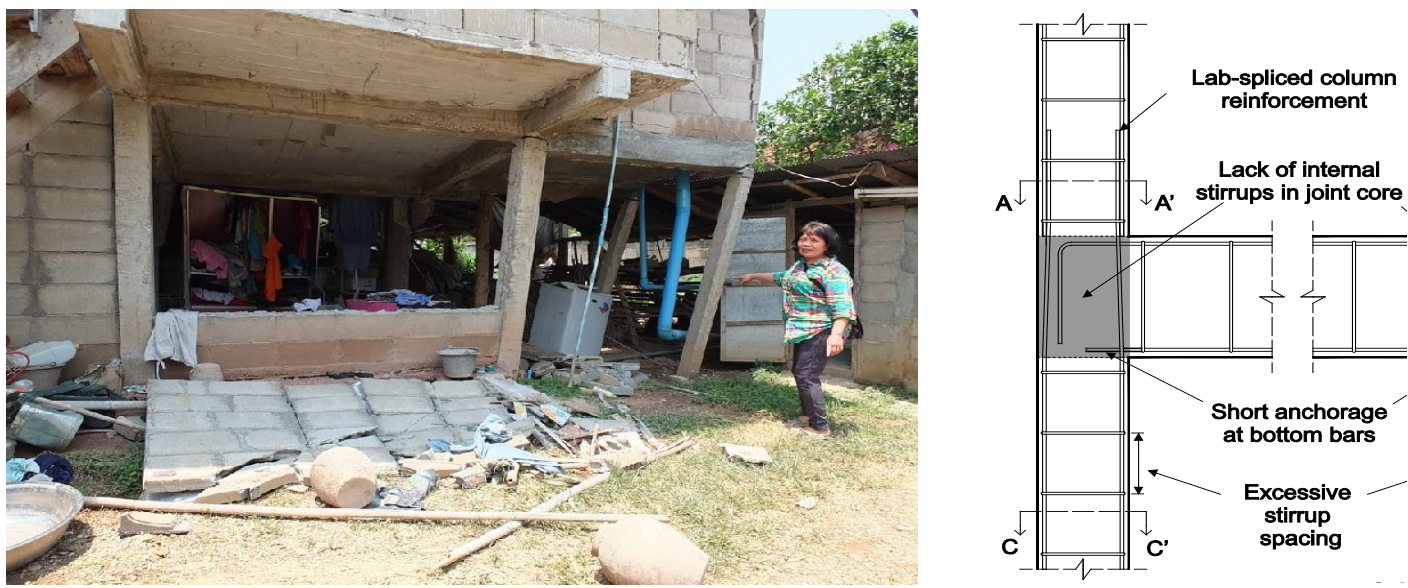

Figure 1 (a) Building partial collapse during the 2014 Mae Lao earthquake (Chaing Rai, Thailand) due to failure of exterior beam-column joints, and (b) typical substandard detailing of beam-column joints in Thailand (adapted from Imjai et al. [6]).

The strengthening of deficient structures is an effective way of reducing vulnerability, losses, and societal risks. Among the different techniques currently available for seismic rehabilitation of reinforced concrete (RC) structures, Post-tensioned Metal Strapping (PTMS) has demonstrated to offer very costeffective solutions to apply 'active confinement' on concrete elements. In rural Thailand, numerous existing concrete structures were built using relatively low strength concrete $(15-20 \mathrm{MPa})$. The application of active confinement with PTMS on low-strength concrete is expected to be extremely effective because low strength concrete expands faster under compression (due to a higher Poisson ratio) than normal/high strength concrete.

This article describes the results from structural engineering assessment through visual inspection of every structural element in the building performed in Phase 1 that was previously reported by the authors [6]. Non-Destructive Tests (NDT) were also used to examine in-situ concrete strength. Such assessment 
http://wjst.wu.ac.th

was used to determine whether further in-depth assessment with Destructive Tests or Strengthening was required. The outcome from the detailed engineering analysis contributes towards promoting the use of innovative strengthening techniques such as Post-tensioned Metal Strapping (PTMS) as strengthening solutions in seismic zones of South East Asia as proposed in the rehabilitation work.

\section{Project facts}

The structural assessment of the structure was divided into two phases: 1) an initial structural assessment to record the history of the building from inception to completion, and subsequent surveying and mapping of defects (including type, magnitude, locations, and severity), and 2) a subsequent Detailed Engineering Assessment (DEA) that involved taking field measuring to obtain accurate information on member properties, dimensions, and position and loading imposed on the structure. Details of both stages are provided in the following sections.

The investigated RC building is the public primary school (Sanchangtai School) located in Northern Thailand (Ampor Pan, Chiang Rai province). The one-story RC building has 7 teaching rooms (13 bays in $\mathrm{X}$ and 3 bays in $\mathrm{Y}$ directions having a typical span of $3 \mathrm{~m}$ - see Figure 2). The building was built in 1998. The cross-section of columns is $200 \times 200 \mathrm{~mm}^{2}$. The columns had a total height of $3 \mathrm{~m}$ and were reinforced with main reinforcement of 4-DB 12 (Yield stress = $295 \mathrm{MPa}$ ) and RB6@200 mm (Yield stress $=235 \mathrm{MPa}$ ) as steel stirrups, having a modulus of elasticity $=200 \mathrm{GPa}$. The wall is made from concrete blocks. The ground slab is $100 \mathrm{~mm}$ thick. Before performing the visual inspection, no drawing/material data were available and the averaged concrete compressive strength was obtained from NDT test as f'c $=17.3 \mathrm{MPa}$, according to ASTM C805 [7]. With such limited information from the construction drawings, detailed engineering assessment (DEA) was subsequently performed by the design team to re-check structural capacity of the as-built concrete members.

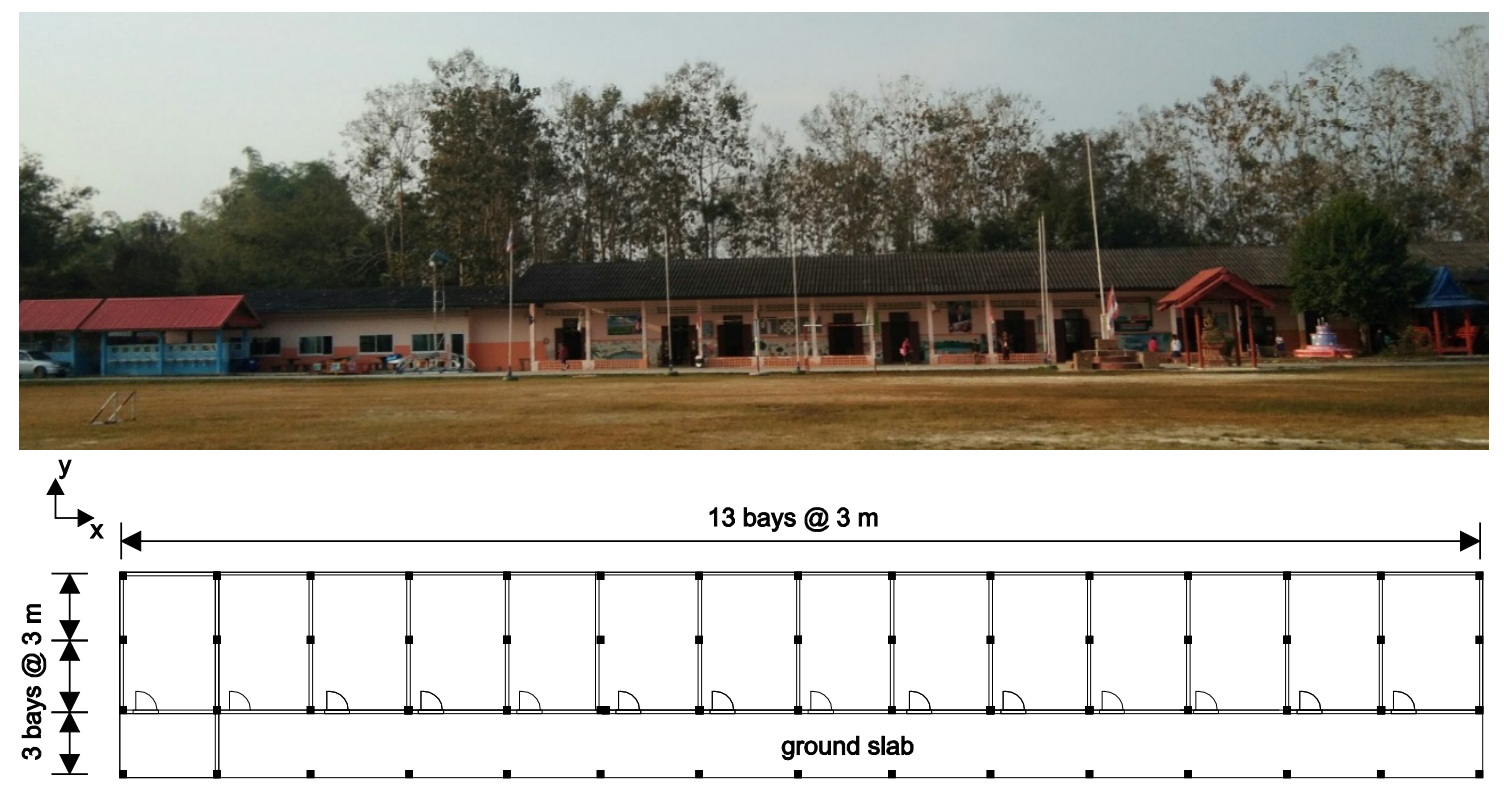

Figure 2 Overview of one-story kindergarten school and column layout.

\section{Structural damage assessment}


http://wjst.wu.ac.th

As part of the Academic Engineering Consultancy Service, the team from Walailak University (WU) was requested to perform a structural integrity investigation of one-story reinforced concrete (RC) building that was damaged during the 2014 Mae Lao earthquake. The team consisted of a local chief engineer and academic experts (WU) to perform a visual inspection to preliminary assess building structural safety based on ACI 364 [8] and RILEM TC 104 [9]. The project was divided into 2 phases; Phase 1 dealt with structural engineering assessment of damaged building and field inspection results from Phase 1 were used to design repair/strengthening solutions in Phase 2.

\section{Structural damage assessment of the $\mathrm{RC}$ building and condition rating}

The condition survey of structural components for the RC building was implemented to examine and assess the current level of damage and deterioration of the structure, and determine the preliminary serviceability condition of the structural components of the building. During the work performed in Phase 1 , the visual inspection was limited to those areas and sections of the damaged RC building that was fully accessible and visible to the inspector teams at the time of inspection. Nothing contained in this article implies that any inaccessible or partly inaccessible area(s) or section(s) of the damaged RC building being inspected by the assessor on the date of the inspection were free from defects latent or otherwise. There could be some difficulties in conducting a visual inspection as some of the main structural elements in a building may have been covered up by architectural finishes. It is, therefore, important that professional judgment is exercised by the structural engineer to determine which areas that are covered up should be exposed for inspection. Reference to structural layout plans to determine the presence of critical structural elements would be crucial under such circumstances. In order to examine the damage condition rating of the building, design checks on load bearing capacity with the actual material properties needs to be considered. The flow chart from preliminary inspection to solution is shown in Figure 3. 


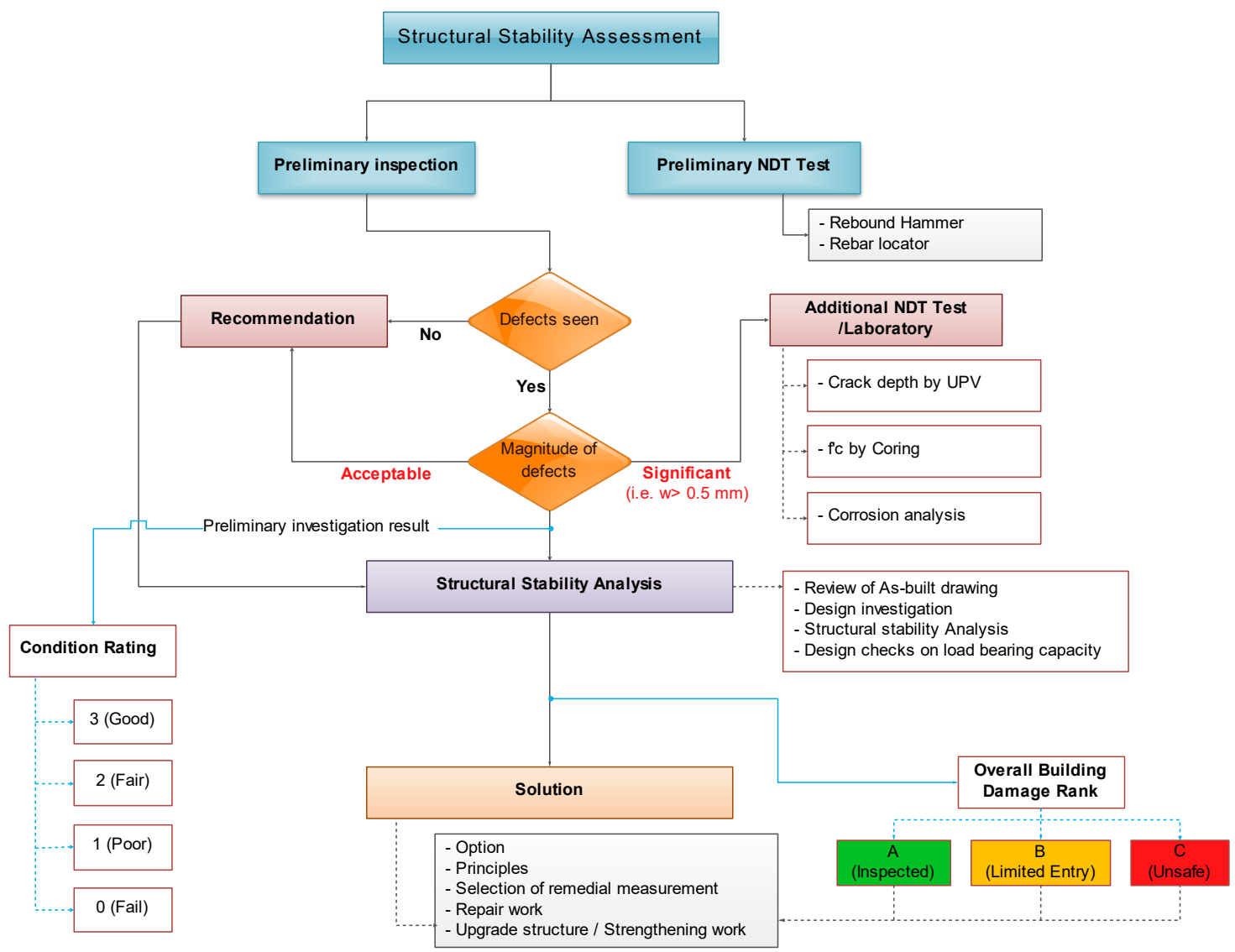

Figure 3 Flow chart from structural condition assessment to solution.

For damages resulting from current loading, repair or replacement terms were added to the criteria for the structure at present condition, i.e. a structural element showing mirror defects, good maintenance and good construction practice will have condition rating of 2 or "Fair condition". If the same element had some defects/damages from current loading to the level that replacement of the element would benefit to the whole structure rather than rehabilitation, then the term "Replacement" would be recommended instead of "Fair condition" (adopted from ACI 364 [10]). No responsibility can be accepted for defects, which are latent or otherwise not reasonably defected on a visual inspection without interference with or removal of any of the structure including fixtures or fittings on the inspected building (e.g. Figure 3). For the purpose of this inspection, an element rating system is developed to properly assess the current condition against the originally intended function of the existing structure. From the field inspection, inspectors have classified the conditions of the structural components into 4 groups as listed in Table 1 adopted from RILEM TC 104 [9].

Table 1 Structural condition rating, action and equivalent floor damaged rank.

\begin{tabular}{lcc}
\hline Conditio & Descriptions & $\begin{array}{c}\text { Building } \\
\text { Damage Rank* }\end{array}$ \\
Rating & Required Action & \\
\hline
\end{tabular}




\begin{tabular}{|c|c|c|c|}
\hline $\begin{array}{l}\text { Conditio } \\
\text { Rating } \\
\end{array}$ & Descriptions & Required Action & $\begin{array}{c}\text { Building } \\
\text { Damage Rank* }\end{array}$ \\
\hline $\begin{array}{c}3 \\
(\text { Good })\end{array}$ & $\begin{array}{l}\text { Element performs intended function with } \\
\text { high degree of reliability. The item or area } \\
\text { inspected appears to be in sound condition } \\
\text { without any significant visible defects. }\end{array}$ & None & \\
\hline $\begin{array}{c}2 \\
\text { (Fair) }\end{array}$ & $\begin{array}{l}\text { Element performs intended function with } \\
\text { small reduction in reliability. No effects on } \\
\text { structural performance and/or instability. }\end{array}$ & $\begin{array}{l}\text { May require some minor } \\
\text { repairs of maintenance, } \\
\text { and /or increase } \\
\text { inspection frequency. }\end{array}$ & $\begin{array}{l}\text { Rank A } \\
\text { or } \\
\text { Rank B }\end{array}$ \\
\hline $\begin{array}{c}1 \\
\text { (Poor) }\end{array}$ & $\begin{array}{l}\text { Element does not perform intended function } \\
\text { with any degree of reliability. The item or } \\
\text { area inspected exhibits some minor defects, } \\
\text { minor damage or deterioration due to age or } \\
\text { lack of maintenance. }\end{array}$ & $\begin{array}{l}\text { Immediate repair or } \\
\text { replacement of } \\
\text { Element. }\end{array}$ & Rank B \\
\hline $\begin{array}{c}0 \\
\text { (Fail) }\end{array}$ & $\begin{array}{l}\text { Element does not perform intended function } \\
\text { at all }\end{array}$ & $\begin{array}{l}\text { Immediate replacement } \\
\text { or Provision of } \\
\text { immediate temporary } \\
\text { support. }\end{array}$ & $\begin{array}{l}\text { Rank B } \\
\text { or } \\
\text { Rank C }\end{array}$ \\
\hline
\end{tabular}

* Note: Equivalent building damage rank is given to the individual floor inspected and the design checks and current loading condition will be accounted for. Damage Rank is shown as

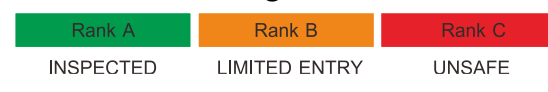

It is, however, noted that a visual inspection (Figures $\mathbf{4}$ and 5) is essential and during the walkround there may be an opportunity to obtain samples of defects/loose concrete or cracks from spalled area that may be easily detached. At this stage, opportunities to view all the structure may be limited, for example, high parts of the structure or hidden areas behind false ceilings.

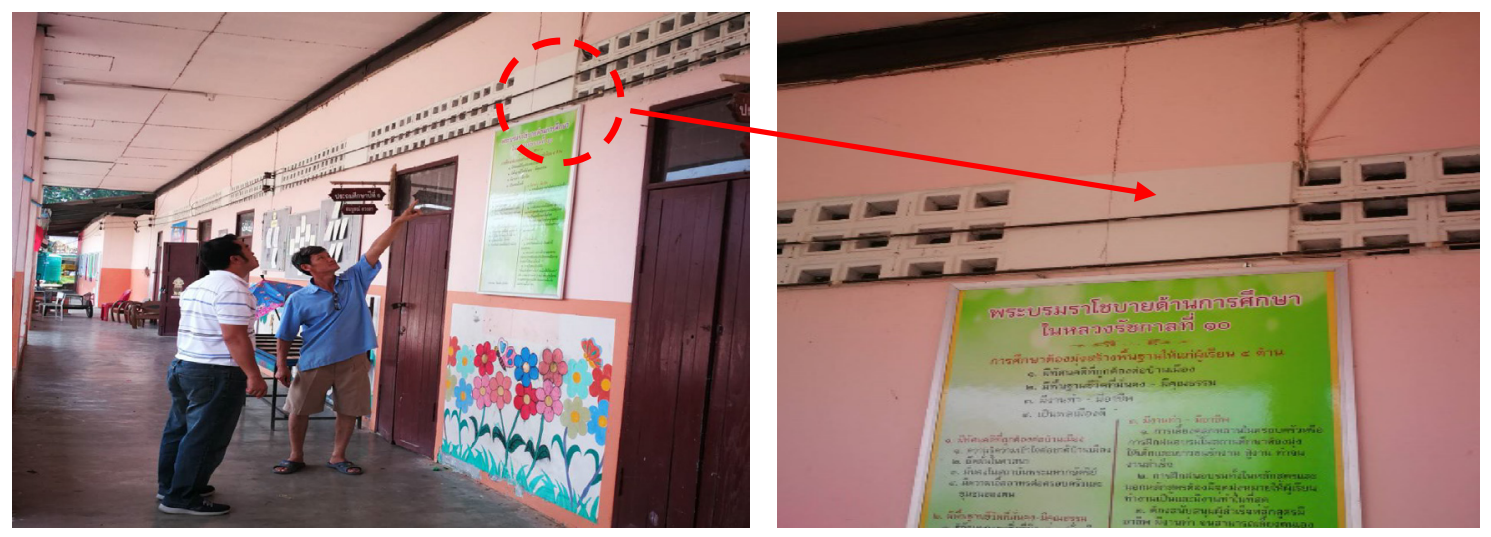

Figure 4 Visual inspection of damaged building performed during phase 1 (photo no. F-01). 


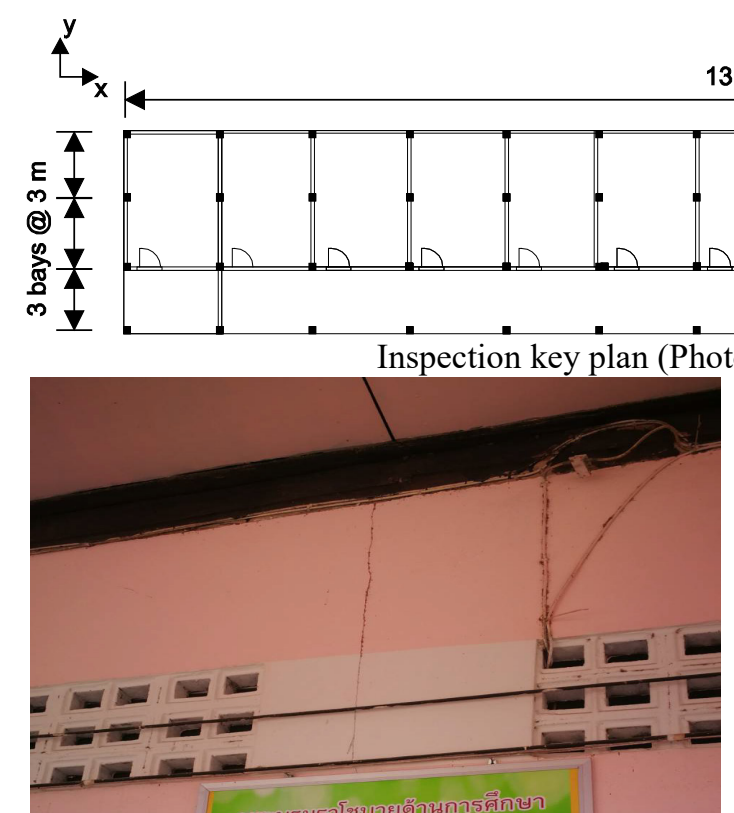

F-01: Vertical crack $(w=0.2 \mathrm{~mm})$, condition rating $=$ "Fair"

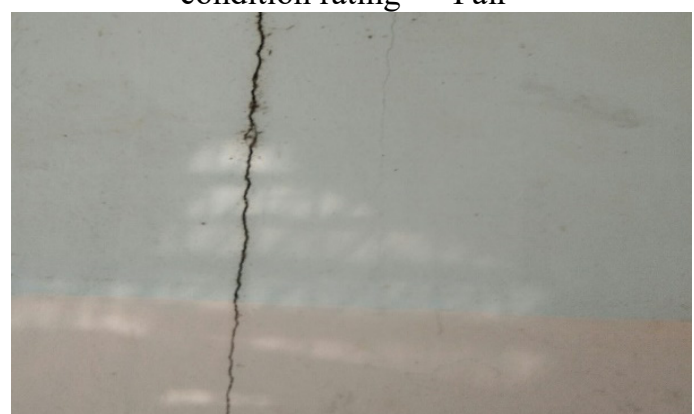

F-03: Vertical crack on wall $(\mathrm{w}=0.2 \mathrm{~mm})$, condition rating $=$ "Fair"
13 bays @ $3 \mathrm{~m}$

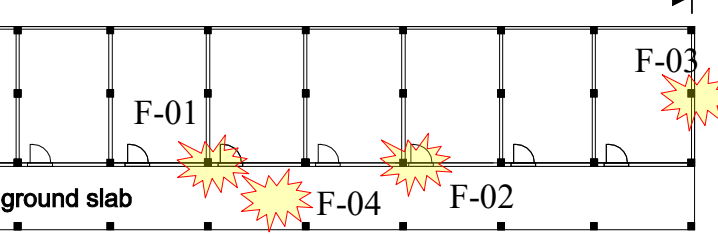

ground slab

no. F-xx is shown below)

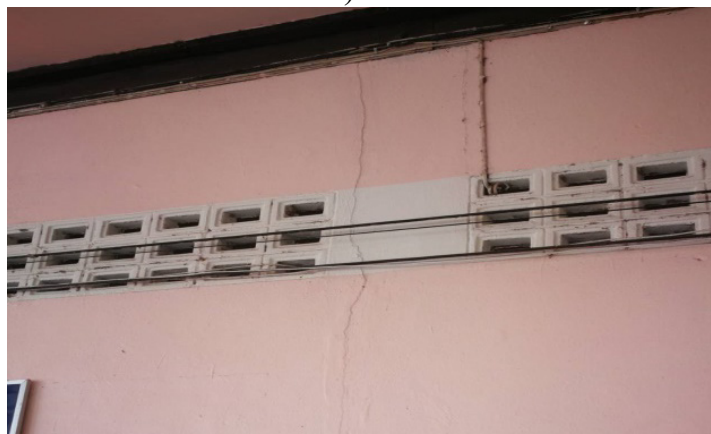

F-02: Vertical crack $(\mathrm{w}=0.15 \mathrm{~mm})$,

condition rating $=$ "Fair"

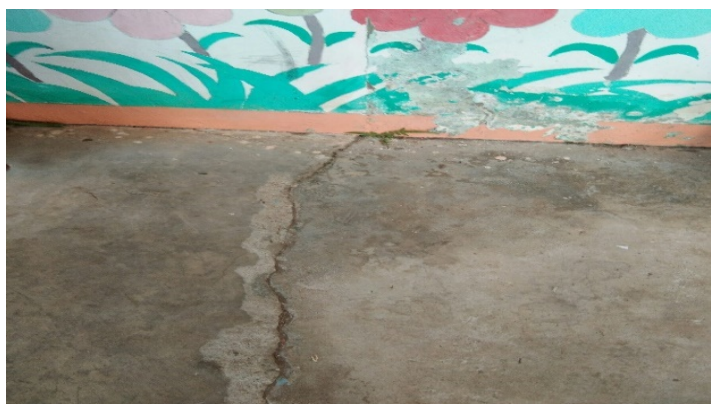

F-04: floor crack ( $\mathrm{w}>2 \mathrm{~mm})$, condition rating $=$ "Poor"

Figure 5 Photos from visual inspection (adapted from the field inspection report by Imjai et al. [6]).

During the visual inspection, a structural condition rating (i.e. Table 1) was given to the inspected structural components such as column, beam, and slab of the building. This rating condition was given according to the damages observed during the field inspection survey only. Damages such as concrete spalls, cracks, bulging are classified according to the degree of damage and rating level ranged from 0 (Fail) to 3 (Good). This condition rating for individual structural components should not be used as a representative damage ranking for the whole building. It is intended to be used as conditional rating for only inspected structural members and thus required action can be specified for those members once the rating condition is given. Crack mapping results from structural engineering assessment performed during Phase 1 were shown in Figure 5.

A preliminary structural assessment and detailed engineering analysis of the $\mathrm{RC}$ building according to ACI 318 [6] indicated that the flexural capacity of the existing RC concrete building was sufficient to sustain the original design live load. Since there was no detailed drawing/material information available at the time of inspection, concrete strength was determined using a rebound hammer, whereas the steel reinforcement was assumed to be steel grade SD30 (fy $=295 \mathrm{MPa}$ ) and SR24 (fy = $235 \mathrm{MPa}$ ) for flexural and shear reinforcement respectively. Concrete covering and reinforcement details were also measured using Ferro scan techniques. This NDT technique gives enough information for further structural analysis. 
http://wjst.wu.ac.th

The design of the original RC members required that the design flexural strength exceeded the required factored moment using the original design live load (L) of $2.9 \mathrm{kN} / \mathrm{m}^{2}$ (public school) (i.e. $\phi \mathrm{Mn}>\mathrm{Mu}$ ). The load combination used in the design checks according to ACI 318 are as follows:

Consider only dead load (L) and live load (L)

$\mathrm{U}=1.4 \mathrm{D}+1.7 \mathrm{~L}$

Taking the earthquake loads $(\mathrm{E})$

$\mathrm{U}=1.05 \mathrm{D}+1.28 \mathrm{~L}+1.4 \mathrm{E}$ or

$\mathrm{U}=0.9 \mathrm{D}+1.43 \mathrm{E}$

In order to determine the earthquake loads (E), the equivalent force method is adopted (UBC [11]), and the base shear force (V) was calculated using Eq. (4).

$\mathrm{V}=\mathrm{ZIKCSW}$

where $\mathrm{I}$ is the Building importance factor, $\mathrm{Z}=$ Seismic Zone factor (the project site is in zone 4 ), $\mathrm{W}=$ total seismic dead load, $\mathrm{K}$ is the building coefficient, $\mathrm{C}$ is the dynamic coefficient of building and $\mathrm{S}$ is the coefficient of soil and building.

Field inspection indicated that the ground concrete slab (thickness $=100 \mathrm{~mm}$ ) had sufficient strength (although without risk of collapse) to resist a certain level of seismic load in case the compact soil underneath the slab failed. It was also evident that the amount of reinforcement in the original design did not comply with the modern seismic design guidelines and, therefore, strengthening work was required to improve the overall structural seismic performance. The use of high ductile metal strapping technique to upgrade existing columns was proposed in Phase 2, as discussed in the following.

\section{Post-tensioned Metal Strapping technique}

Previous research at the University of Sheffield [12] led to the development of the Post-tensioned Metal Strapping (PTMS) technique. The technique used ductile high-strength steel straps post-tensioned around RC elements using strapping tools as those used in the packaging industry (see Figure 6a) Metal straps are commercially available in various thicknesses, widths, and strengths. The ease of handling and strengthening objective determine the strap dimensions. Typical metal strap yield strengths vary between 300 and 1,000 MPa. Two types of tensioning machines exist i) pneumatic, in which the tension force is regulated accurately by applied air/hydraulic pressure (see Figure 6b), or ii) manual, in which the tension force is controlled by the operator. A cylindrical specimen confined using an air-powered tensioning machine is shown in Figure 6c. This method has demonstrated to be effective in strengthening mediumscale RC members subjected to monotonic loading (see Figures 6d-6e) [13-15]. The low cost of the materials and the ease and speed of application make this technique very effective for the repair and strengthening of existing deficient RC buildings. However, corrosion of the mild-steel clip lock becomes an issue when using this technique and becomes one of the main issues when using PTMS for retrofitting concrete buildings in harsh/wet environmental conditions. Moreover, the technique requires pre-tension using pneumatic air pressure and the creep effect on the pre-tensioned straps may be required particular attention for long-term application. Recent extensive research work at Walailak University (WU) by Imjai et al. [16-18], performed a series of creep tests on PTMS to verify the effectiveness and applicability of the high ductile Post-tensioned Metal Strapping (PTMS) technique at different scale levels led to the development of a durable Post-tensioned Metal Straps for retrofitting RC beams and columns. 

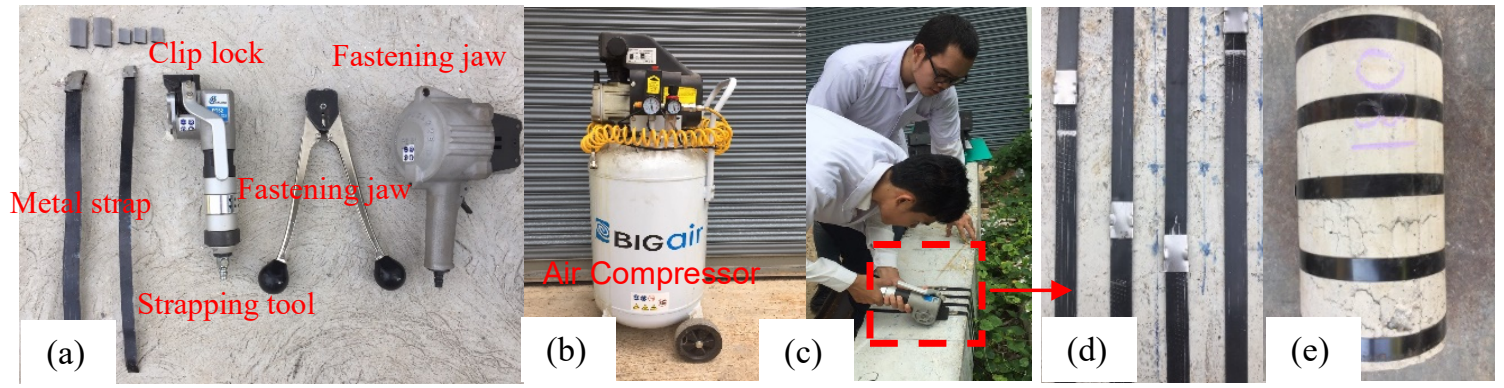

Figure 6 Photos from visual inspection (adapted from Imjai et al. [17]).

\section{Design equation for confined concrete columns using PTMS}

The ductility of RC members depends not only on the cross-section characteristics such as percentage and distribution of longitudinal reinforcement and levels of axial load, but also on the amount of lateral confinement. Ma et al. [19] also proposed a confinement model specifically for high strength concrete (HSC) columns and they also numerical models for circular HSC columns confined with metal straps. The predictive model is based on the close-form equations proposed by Mander et al. [20] for describing the stress-strain relationship of confined concrete members. The model was later calibrated by Awang et al. [21] based on 140 HSC concrete columns with the confinement ratio ranging from 0.06 to 0.86 . The concrete compressive strength $\left(f_{c c}\right)$ and strain $\left(\varepsilon_{c c}\right)$ of confined concrete can be expressed as;

$f_{c c}=f_{c o} 2.62\left(\rho_{v}\right)^{0.4}$

$\varepsilon_{c c}=\varepsilon_{c o} 11.60\left(\rho_{v}\right)$

where $\rho_{v}$ is the volumetric confinement ratio of steel strap $\left(\rho_{v}=V_{s} f_{y} / V_{c} f_{c o}\right)$, and are the volumes of straps and confined concrete, respectively. $f_{y}$ is the yield strength of steel strap, $\varepsilon_{c o}$ is the ultimate strain of unconfined concrete $(=0.0035)$.

It should be noted that Eqs. (1) and (2) were proposed for circular confined concrete columns and for rectangular confined section, non-uniformity of confinement induced by strapping forces can significantly reduce at the corners of the sections. Mirmiran et al. [22] introduced the shape factor into the volumetric confinement ratio $\left(\rho_{v}\right)$ as;

$\rho_{v}=\frac{V_{s} f_{y}}{A_{e} L_{e} f_{c o}}$

and effective confinement area $\left(A_{e}\right)$ can be expressed as;

$A_{e}=\frac{\left(1-\left(\frac{b}{h}\right)\left(h-2 R_{c}\right)^{2}+\frac{\left(\frac{h}{b}\right)\left(b-2 R_{c}\right)^{2}}{3 A_{g}}-\rho_{s c}\right) A_{c}}{1-\rho_{s c}}$

where $b$ and $h$ are width and height of column section, respectively (in the case of a square section, $b=$ $h) ; A_{g}$ is the gross area of column section; $L_{e}$ is the length of confined region; $A_{c}$ is the total area of concrete; $R_{c}$ is the corner radius; and $\rho_{s c}$ is the cross-sectional area ratio of longitudinal steel. 
http://wjst.wu.ac.th

The capacity of confined concrete columns can be calculated by using cracked sectional analysis. Force equilibrium and strain compatibility requirements are used to calculate the ultimate load of unstrengthened and strengthened sections. The RC columns with $3,000 \mathrm{~mm}$ height with a $150 \times 150 \mathrm{~mm}^{2}$ cross section (Figure 13a). Four $\phi 12 \mathrm{~mm}$ mild-steel bars were considered as main reinforcement in all of columns. Shear spans were reinforced in shear with $6 \mathrm{~mm}$ steel stirrups (2 legs) at a spacing of $120 \mathrm{~mm}$. The calculated interaction diagram of existing RC columns obtained the crack-sectional analysis shown in Figure 7, is compared to the confined concrete columns with 2 layers of $0.8 \times 25 \mathrm{~mm}^{2}$ metal straps having the yield strength $=800 \mathrm{MPa}$, ultimate strength $=950 \mathrm{MPa}$, respectively. The strengthening of the columns resulted in an increase in the axial load carrying capacity by up to $120 \%$, enabling the column to behave in a more ductile manner.
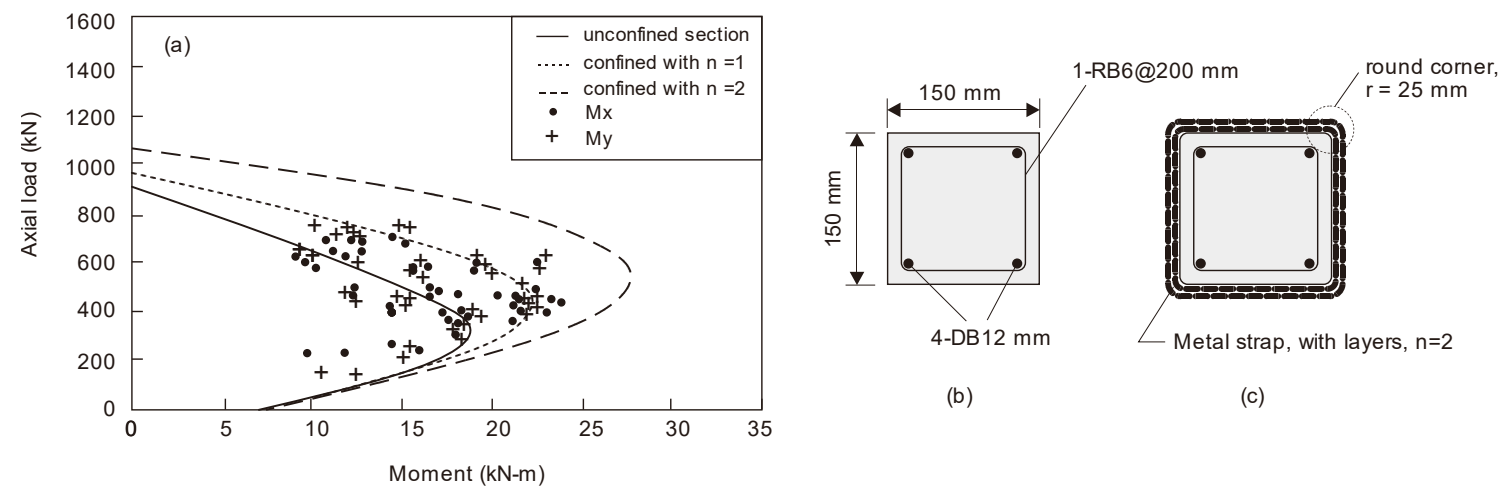

(b)

(c)

Figure 7 Seismic strengthening of concrete columns; (a) interaction P-M diagram, (b) unstrengthen section and (c) strengthened section with 2 layers of metal straps.

\section{Stress relaxation, Construction quality control and fire protection}

All of the strengthened sections were confined externally with metal strips of $25 \mathrm{~mm}$ width and 0.8 $\mathrm{mm}$ thickness. The width and thickness of the strip were limited to the referred dimensions because of the small section size of the specimens. This high ductile metal strap with epoxy coated and wax finishing, was supplied by Strapping Center, Co. Ltd (Thailand). The clip efficiency is also affected by the type and operational condition of the sealing machine used. The efficiency with single or double notch sealing depends on the friction induced as a result of the out of plane bending of the clip. This out of plane bending is associated with the breaking of the strip and, therefore, the reduction of its dimensions and ultimate strength. An attempt was made to improve the connection efficiency by avoiding the breaking of the strip in 2 positions which was the case with the single notch connection. The cutting jaws of the sealing tool were modified to cause deliberate damage on the strip only on one side, as shown in Figure 8. The result was that the strips slipped at a much lower load than the one obtained with the proper single notch clips.

The loss in prestressing force in the strip was measured following the sealing application. This is due to the lifting imposed on the strip during the sealing of the clip by the sealing tool. Stress relaxation due to creep effect was also performed by the authors to investigate this reduction of prestress in 6 coupons $\left(25 \times 0.8 \mathrm{~mm}^{2}\right.$ strip) secured with single and double notch clips. The setup shown in Figure 8a was used to perform the tests for 1 month, the results of which are plotted in Figure $\mathbf{8 b}$. It can be seen that the average prestress loss after sealing at an applied air pressure of 8 bars (116 psi), was approximately equal to $4 \%$ 
and $15 \%$ of the initial stress $(330 \mathrm{MPa})$, as measured single notch and double notches sealing applications.
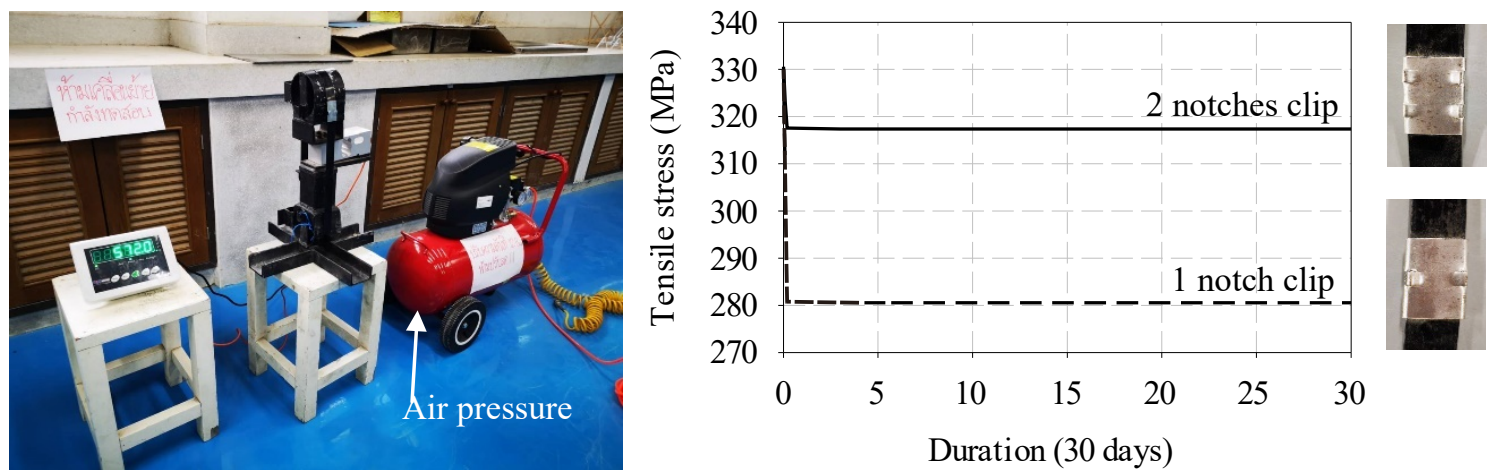

Figure 8 Test setup for creep test (a) and stress relaxation test result over 30 days period (b).

Figures 9 and 10a - 10b show the installation of metal straps on existing RC columns. Following the installation of the straps, two layers of epoxy coating was applied on the PTMS (Figure 10c) as a fire protection system similar to the externally bonded CFRP system i.e. [23,24].

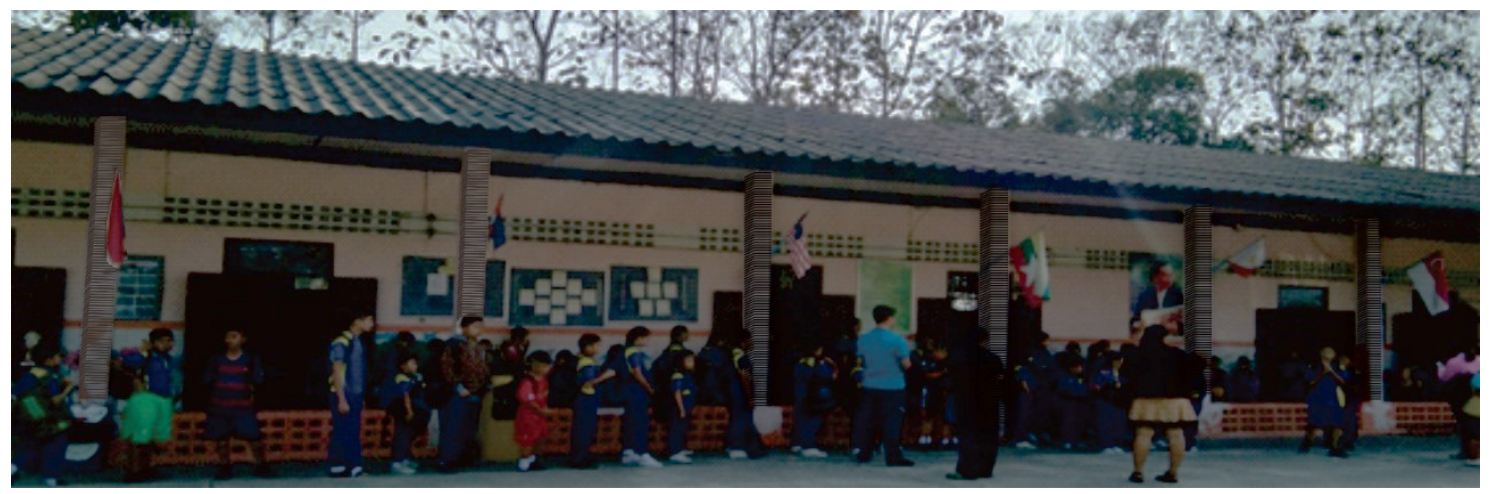

Figure 9 Strengthening of concrete columns after installation of PTMS in the building 1 (front view). 

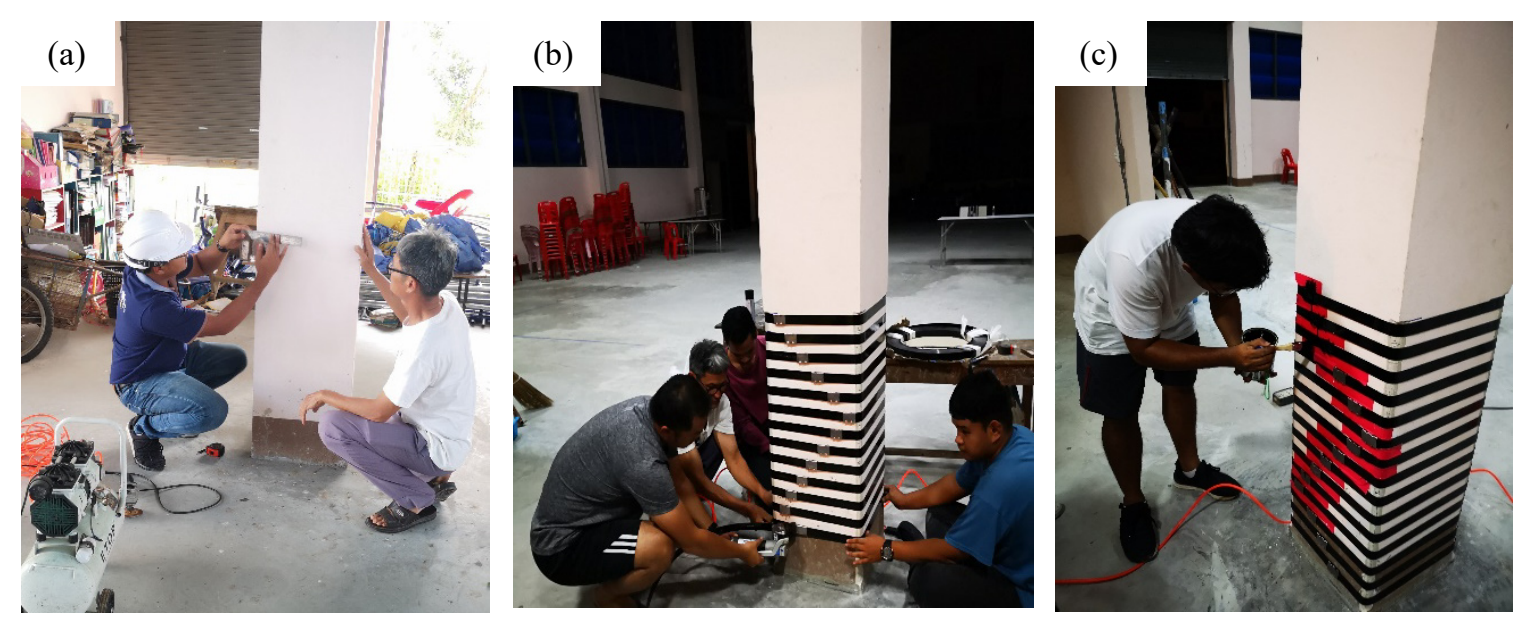

Figure 10 Installation of Post-tension metal straps (PTMS) on a RC column (Gymnasium building).

\section{Concluding remarks}

This article presented a case study on the seismic strengthening of a one-story RC kindergarten school located in Chaing Rai province, Thailand. The building was partially damaged during the 2014 Chaing Rai earthquake and required a two work Phases: 1) an initial structural assessment, and 2) a Detail Engineering Assessment (DEA). The DEA found that the building required structural strengthening and therefore an innovative strengthening technique was used for the first time in a real case study structure. Based on the case study discussed in this paper, the following conclusions are drawn:

- Design verifications based on ACI 318 and load combination using UBC code showed that the flexural and axial capacity of the original concrete columns were insufficient to resist excessive earthquake loads. PTMS systems was successful in increasing the axial capacity of original low strength concrete columns $\left(\mathrm{f}_{\mathrm{c}}=17.3 \mathrm{MPa}\right)$ by up to $120 \%$ compared to their original design capacity.

- During the visual inspection, vertical cracks found on the concrete wall with a maximum crack width of $0.2 \mathrm{~mm}$ which was rated as "Fair" condition. Thus, this damaged wall required repair work. For ground slab, it was found that a $2 \mathrm{~mm}$ crack width occurred at the columns and, thus, was rated as "Poor", which required urgent repair work.

- Reduced prestressing force recorded by up to 4 and $15 \%$ of the initial prestress in the metal straps for 1 notch and double notches sealing applications, respectively. This was due to the lifting imposed on the strip during the sealing of the clip by the sealing tool.

- Seismic upgrading of low strength concrete columns was performed using Post-tensioned Metal Strapping system and an existing design equation was employed to determine the confinement efficiency.

- The application of epoxy coating was applied on the PTMS as a fire protection and long-term durability requirement.

- It is proven that crack repair and innovative Post-tensioned Metal Strapping can be used to upgrade existing/damaged RC buildings for future seismic occurrence.

\section{Acknowledgements}

This project is funded by National Research Council of Thailand. The authors are also thankful to Mr. Sunan Somsrida, Director of the Sanchangtai School, Ampor Pan, Chiang Rai province, for providing access to the field inspection work of the project. This project was partially supported by TRF Senior Research Scholar (RTA6280012). 
http://wjst.wu.ac.th

\section{References}

[1] P Lukkunaprasit, A Ruangrassamee, T Boonyatee, C Chintanapakdee, K Jankaew, N Thanasisathit and T Chandrangsu. Performance of structures in the Mw 6.1 Mae Lao earthquake in Thailand on May 5, 2014 and implications for future construction. J. Earthq. Eng. 2015; 20, 219-42.

[2] BZ Koru. Seismic Vulnerability Assessment of Low-Rise Reinforced Concrete Buildings. Ph.D. Thesis, Purdue University, West Lafayette, IN, 2002.

[3] R Garcia, I Hajirasouliha and K Pilakoutas. Seismic behaviour of deficient RC frames strengthened with CFRP composites. Eng. Struct. 2010; 32, 3075-3085.

[4] I Bedirhanoglu, A Ilki, S Pujol and N Kumbasar. Behavior of deficient joints with plain bars and low-strength concrete. ACI Struct. J. 2010; 107, 300.

[5] M Rizwan, N Ahmad and AN Khan. Seismic performance assessment of reinforced concrete moment resisting frame with low strength concrete. Structures 2020. https://doi.org/10.1016/j.istruc.2020.10.038

[6] $\mathrm{T}$ Imjai, S Suthiprabha and $\mathrm{T}$ Thirawetchayan. Structural engineering assessment for seismic damaged concrete building: A case study of one story kindergarten school. In: Proceedings of the $9^{\text {th }}$ Rajamangala University of Technology International Conference. Trang, Thailand, 2018.

[7] ASTM C805/C805M - 18. Standard Test Method for Rebound Number of Hardened Concrete.

[8] ACI 364.1. Guide for Evaluation of Concrete Structures Prior to Rehabilitation. 1999, p. 22.

[9] $\mathrm{T}$ Javor. Damage classification of concrete structures. The state of the art report of RILEM Technical Committee 104-DCC activity. Mater. Struct. 1991; 24, 253-9.

[10] ACI 318. Building Code Requirements for Structural Concrete and Commentary. B.M Johnson and A.H. Wilson, Terminology of Building Conservation Industry, Division of Building Research, NRC Canada.

[11] International Conference of Building Officials. 1997. 1997 Uniform Building Code. Vol. 2, p. 2-1, $2-38$.

[12] M Frangou, K Pilakoutas and S Dritsos. Structural repair strengthening of RC columns. Constr. Build Mater. 1995; 9, 259-66.

[13] GY Gunja. Seismic Strengthening of Reinforced Concrete Structures. Ph.D. Thesis, University of Sheffield, Sheffield, UK, 2005.

[14] M Frangou, K Pilakoutas and S Dritsos. The structural repair/strengthening of RC columns. Constr. Build Mater. 1995; 9, 259-66.

[15] CK Ma, AZ Awang, W Omar, M Liang, SW Jaw and M Azimi. Flexural capacity enhancement of rectangular high-strength concrete columns confined with post-tensioned steel straps: Experimental investigation and analytical modelling. Struct. Concr. 2016; 7, 668-76.

[16] T Imjai, U Chaisakulkiet, R Garcia and K Pilakoutas. Strengthening of RC members using Posttensioned Metal Straps: State of the research. Lowl. Tech. Int. 2018; 20, 187-96.

[17] T Imjai, M Setkit, R Garcia and FP Figueiredo. Strengthening of damaged low strength concrete beams using PTMS or NSM techniques. Case Stud. Constr. Mater. 2020; 13, e00403.

[18] M Setkit, T Imjai, U Chaisakulkiet, R Garcia, K Dangyem, K Sanupong and W Chamnankit. Torsional strengthening of low-strength $\mathrm{RC}$ beams with post-tensioned metal straps: An experimental investigation. Walailak J. Sci. Tech. 2020; 17, 1399-411.

[19] CK Ma, AZ Awang, W Omar and L Maybelle. Experimental tests on SSTT-confined HSC columns. Mag. Concr. Res. 2016; 66, 1084-94.

[20] JB Mander, MJN Priestely and R Park. Theoretical stress-strain model for confined concrete. $J$. Struct. Eng. 1988; 114, 1805-26.

[21] AZ Awang, W Omar, MC Khun and M Liang. Design equation for SSTT-confined circular HSC columns. Int. J. Res. Eng. Tech. 2013; 2, 331-6.

[22] A Mirmiran, M Shahawy, M Samaan, HE Echary, JC Mastrapa and OG Pico. Effect of column parameters on FRP-confined concrete. J. Compos. Constr. 1998; 2, 175-85.

[23] T Imjai, R Garcia, M Guadagnini and K Pilakoutas. Strength degradation in curved Fiber-reinforced Polymer (FRP) bars used as concrete reinforcement. Polymers 2020; 12, 1653. 
http://wjst.wu.ac.th

[24] T Imjai, M Guadagnini and K Pilakoutas. Curved FRP as concrete reinforcement. Proc. Inst. Civ. Eng. Eng. Comput. Mech. 2009; 162, 171-8. 